\title{
PENGARUH PENGGUNAAN BAHAN AJAR MATEMATIKA BERSUPLEMEN KOMIK TERHADAP KEMANDIRIAN BELAJAR SISWA
}

\author{
Mochamad Guntur ${ }^{1}$, Arif Muchyidin², Widodo Winarso ${ }^{3}$
}

\author{
Tadris Matematika \\ Institut Agama Islam Negeri (IAIN) Syekh Nurjati Cirebon \\ Email: aaguntur2@gmail.com ${ }^{1)}$,wak_badjra@yahoo.com ${ }^{2)}$,widodoiain@gmail.com ${ }^{3)}$
}

\begin{abstract}
Mathematics is a lesson that many students do not like, so to change it all required interactive teaching materials that can foster student self-reliance. The purpose of this research is to know whether there is influence of response of the use of mathematics material supplement comic to student self-reliance. The subjects used in this study are the students of class VIII at MTs Islmic Center. The method used in this research is descriptive statistical method with research design The One-Shot Case Study Design. Response of class B comic usage is in good category with get percentage equal to $69,90 \%$ and response of class $C$ using comic in good category with get percentage equal to $72,32 \%$. The independence of class $A$ is in the high category to obtain a percentage of $52.22 \%$, the independence of studyi class B is in the high category that obtained a percentage of $65.37 \%$, and the independence of class $C$ study is in the high category obtaining the procession $66.07 \%$. The result of hypothesis obtained $F_{\text {count }}=17,198$ and $F_{\text {table }}=3,14$ based on Ha hypothesis criteria.
\end{abstract}

Keywords: Teaching Materials, Comic Mathematics, Independence.

\section{PENDAHULUAN}

Undang-Undang Republik Indonesia Nomor 20 tahun 2003 menyatakan bahwa pendidikan adalah usaha sadar dan terencana untuk mewujudkan suasana belajar dan proses pembelajaran agar peserta didik secara aktif mengembangkan potensi dirinya untuk memiliki kekuatan spiritual keagamaan, pengendalian diri, kepribadian, kecerdasan, akhlak mulia, serta keterampilan yang diperlukan dirinya, masyarakat, bangsa dan negara. Pembelajaran adalah suatu proses dimana lingkungan seseorang secara disengaja dikelola untuk memungkinkan seseorang turut serta dalam tingkah laku tertentu dalam kondisi-kondisi khusus. Pembelajaran merupakan aspek kegiatan manusia yang kompleks, yang tidak sepenuhnya dapat dijelaskan. Pembelajaran secara simpel dapat diartikan sebagai produk interaksi berkelanjutan antara pengembangan dan pengalaman hidup. Pembelajaran dalam makna kompleks adalah usaha sadar dari seorang guru untuk membelajarkan siswanya (mengarahkan interaksi siswa dengan sumber belajar lainnya) dalam rangka mencapai tujuan yang diharapkan. (Hakim, 2009: 20).
Sedangkan tujuan pembelajaran menurut Suardi (2015: 50) adalah untuk memfasilitasi siswa dalam penumbuhan dan pengembangan kesadaran belajar, sehingga mampu melakukan olah pikir, rasa, dan raga dalam memecahkan masalah kehidupan di dunia nyata. Sesuai dengan pernyataan di atas menurut Nurseto (2011: 20) juga mengemukakan bahwa tujuan pembelajaran adalah terjalinnya suatu komunikasi antara murid dan guru sehingga proses pembelajaran di dalam kelas menjadi aktif.

Beberapa pernyataan di atas menunjukan bahwa pendidikan tidak akan luput dari proses belajar mengajar. Proses mengajar yang dimaksud ialah proses dimana ada interaksi antara siswa dan guru, sehingga suasana belajar di kelas menjadi aktif dan tidak berpusat pada guru melainkan siswa yang menjadi pusat pembelajaran. Begitupun dengan pembelajaran matematika yang menerapkan sutau proses pembelajaran yang interaktif dan komunikatif antara siswa dan guru.

Menurut Suardi (2015: 1) belajar matematika adalah berpikir dan berbuat atau mengajarkan matematika. Dengan demikian belajar matematika tidak hanya menyampaikan materi, memberikan contoh, dan latihan semata akan tetapi pembelajaran matematika menerapkan 
suatu proses pembelajaran yang interaktif, sehingga siswa akan berfikir dan berbuat untuk melakukan sesuatu hal yang dapat membuatnya mengerti dalam proses pembelajaran matematika.

Namun pada umumnya pembelajaran matematika di sekolah tingkat SD, SMP, SMA mengalami kesulitan saat belajar matematika, diantaranya kesulitan untuk mengaplikasikan rumus-rumus matematika dalam kehidupan sehari-hari, kesulitan belajar matematika juga disebabkan oleh tekanan yang berlebihan pada hafalan rumus dan kecepatan berhitung sehingga saat mempelajari matematika siswa merasa kurang bermakna dan kurang menyenangkan. (Supriyanto, 2014: 166)

Sebagai upaya memberikan pembelajaran yang menyenangkan, maka diperlukan media pembelajaran yang menarik. Menurut Hosnan (2014: 63) media pembelajaran adalah segala sarana atau bentuk komunikasi nonpersonal yang dapat dijadikan wadah dari informasi pelajaran yang akan disampaikan kepada peserta didik, serta dapat menarik minat dan perhatian, sehingga tujuan daripada belajar dapat tercapai dengan baik. Dengan demikian bahwa media pembelajaran adalah segala sesuatu yang dapat digunakan sebagai alat bantu komunikasi pengantar dalam proses pembelajaran, yang membawa konsep atau informasi tentang materi pelajaran.

Salah satu media yang menarik yang dapat mengaitkan materi dengan kejadian sehari-hari dalam kehidupan nyata ialah media komik, Menurut Nuroeni (2013: 79) dalam penelitiannya menyatakan bahwa komik adalah salah satu media yang sekarang ini mulai digunakan untuk pembelajaran terutama bagi anak-anak, hal ini disebabkan kecenderungan pada siswa yang tidak menyukai buku teks yang tidak menarik.

Pendapat di atas dilengkapi oleh Daryanto (2010: 127) dalam penelitiannya menyatakan bahwa komik memiliki 5 kelebihan jika dipakai dalam pembelajaran yakni: (1) Komik dapat meningkatkan partisipasi individu sehingga dapat memotivasi siswa dalam belajar, (2) Visual juga dapat menumbuhkan minat siswa dan dapat memeberikan hubungan antara isi materi pelajaran dengan dunia nyata, (3) Komik berbeda dengan film atau animasi, komik merupakan media yang permanen. Jika siswa tidak memahami suatu adegan film atau animasi, siswa tidak bisa mengulanginya berbeda halnya dengan komik siswa dapat mengulangi sesuka hati, (4) Komik merupakan media yang populer.

Menurut Karmawati (2007: 127) menyatakan bahwa pembelajaran menggunakan komik dapat memberikan suatu kegiatan pembelajaran dalam suasana gembira dan menyenangkan bagi anak, karena peserta didik dapat mendapatkan sesuatu yang berbeda dalam pembelajarannya yakni ada gambar, ilustrasi kejadian nyata dalam kehidupan sehari-hari, sehingga peserta didik dapat menghilangkan pikiran bahwa belajar matematika itu membosankan dan akan membuat peserta didik menajdi mandiri untuk belajar matematika.

Sehingga dengan adanya media komik sebagai bahan ajar diharapkan akan menumbuhkembangkan kemandirian belajar siswa. Media ini akan meningkatkan rasa ketertarikan peserta didik untuk mempelajarinya di rumah maupun di sekolah ataupun di tempat bermain. Menurut Kartadinata (2007: 10) mengatakan bahwa perilaku mandiri adalah perilaku memelihara hakekat eksistensi diri. Dari pernyataan tersebut kita dapat kembangkan yaitu sikap kemandirian perlu dikembangkan pada diri siswa sejak dini. Hal ini dilakukan dalam rangka membentuk karakter siswa yang dapat berdiri sendiri sehingga ia akan tumbuh menjadi pribadi yang mampu berinisiatif, penuh kreatifitas, disiplin dan bertanggung jawab.

Kegiatan pembelajaran, kemandirian sangat penting karena kemandirian merupakan sikap pribadi yang sangat diperlukan oleh setiap individu. Menurut Sumarmo (2006: 5) menyatakan bahwa dengan kemandirian, peserta didik cenderung belajar lebih baik, mampu memantau, mengevaluasi, dan mengatur belajarnya secara efektif, menghemat waktu secara efesien, akan mampu mengarahkan dan mengendalikan dirinya sendiri dalam berfikir dan bertindak, serta tidak merasa bergantung pada orang lain secara emosional.

Pada penelitian ini yang menjadi subjek penelitian adalah siswa SMP/MTs kelas VIII, dimana kemampuan abstraksi siswa masih rendah, Menurut Soviawati (2011: 83) menyatakan bahwa abstraksi siswa SMP/MTs masih rendah sehingga abstraksi juga menjadi salah satu alasan utama gagalnya proses pembelajaran 
matematika. Fenomena tersebut jika ditinjau dari karakteristik matematika, yang memiliki objek kajian bersifat abstrak, maka dibutuhkan suatu proses yang dapat membawa siswa memahami hal-hal yang abstrak tersebut dalam suatu proses pembelajaran.

Secara sederhana dalam konteks pendidikan matematika, abstraksi dapat diartikan sebagai suatu proses mempelajari ide-ide, objek-objek atau konsep-konsep yang bersifat abstrak. Konsep-konsep yang abstrak dalam matematika tersebut dapat dipelajari melalui proses abstraksi empiris maupun melalui abstraksi matematis (beberapa ahli ada yang menyebutnya sebagai abstraksi reflektif atau abstraksi teoretis). Proses abstraksi tersebut berlangsung melalui serangkaian aktivitas pembelajaran yang melibatkan berbagai aspek pembelajaran. Salah satu aspek yang cukup penting dalam proses pembelajaran matematika adalah visualisasi materi sehingga salah satu media yang cocok adalah komik.

\section{KAJIAN TEORI}

\section{Bahan Ajar Komik}

Bahan ajar adalah segala bentuk bahan yang digunakan untuk membantu guru atau instruktur dalam melaksanakan kegiatan belajar mengajar di kelas. Bahan yang dimaksud bisa berupa bahan tertulis maupun tidak tertulis (Nugraha, 2013: 28). Pendapat lain mengenai bahan ajar yaitu menurut Nalurita (2013: 48) menyatakan bahwa bahan ajar dapat dibuat dalam berbagai bentuk sesuai dengan kebutuhan dan karakteristik materi ajar yang akan disajikan. Untuk itu bahan ajar hendaknya disusun agar siswa lebih aktif dalam kegiatan pembelajaran. Bahan ajar merupakan informasi, alat dan teks yang diperlukan guru atau instruktur untuk perencanaan dan penelaahan implementasi pembelajaran.

Penggunaan bahan ajar berfungsi sebagai berikut: (1) pedoman bagi guru yang akan mengarahkan semua aktivitasnya dalam proses pembelajaran, sekaligus meruapakan substansi kompetensi yang seharusnya diajarkan kepada siswa, (2) pedoman bagi siswa yang akan mengarahkan semua aktivitasnya dalam proses pembelajaran, sekaligus merupakan substansi kompetensi yang seharusnya dipelajari atau dikuasai, (3) alat evaluasi pencapaian atau penguasaan hasil pembelajaran (Widodo \& Jasmadi, 2008: 42).Sedangkan tujuan bahan Ajar tujuan dari pembuatan bahan ajar sebagai berikut: (1) Membantu peserta didik dalam mempelajari sesuatu, (2) Menyediakan berbagai jenis pilihan bahan ajar, sehingga mencegah timbulnya rasa bosan pada peserta didik, (3) Memudahkan peserta didik dalam melaksanakan pembelajaran, dan (4) Kegiatan pembelajaran lebih menarik (Prastowo, 2011: 78). Salah satu media yang dapat digunakan dengan melihat fungsi di atas adalah komik.

Menurut Nuroeni (2013: 80) menjelaskan bahwa salah satu media pembelajaran yang dapat digunakan dalam pembelajaran matematika adalah dengan multimedia komik pembelajaran. Komik adalah salah satu media yang sekarang ini mulai digunakan untuk pembelajaran terutama bagi anak-anak. Hal ini disebabkan kecenderungan pada siswa yang tidak begitu menyukai buku teks karena tidak menarik. Padahal secara empirik siswa cenderung lebih menyukai buku yang bergambar, yang penuh warna dan visualisasi dalam bentuk realistik maupun kartun.

Menurut Zulkifli (2010: 16) Secara sepintas komik dipandang hanya sebagai media visual yang terdiri dari kumpulan gambar dan tulisan yang terjalin menjadi sebuah cerita. Namun bagi para komikus, komik memiliki unsur-unsur yang terdiri dari sampul depan, halaman isi, dan sampul belakang. Pada halaman sampul depan sebuah komik biasanya terdapat komponenkomponen sebagai berikut: (1) Judul cerita atau judul serial yang sengaja di angkat untuk menarik perhatian pembaca (2) Credits keterangan penulis, penggambar, dan sebagainya (3) Indicia keterangan tentang penerbit.

Sedangkan menurut Zulkifli (2010: 18) pada halaman isi komik terdiri dari: (1) Panel yang berfungsi sebagai ruang tempat diletaknya gambar (2) Gang yang berfungsi ruang atau jarak yang menjembatani antara satu panel dengan panel lainnya (3) Narasi yang berfungsi menerangkan dialog, waktu, tempat, kejadian, dan situas (4) Balon Kata yang berfungsi sebagai menempatkan tulisan biasanya berbentuk bulatan. Halaman sampul belakang tertera ringkasan cerita yang terdapat dalam komik tersebut untuk memberikan gambaran umum tentang isi komik kepada pembaca. 
Menurut Ripai (2013: 80) kekurangan komik diantaranya: (1) Komik mengalihkan perhatian anak dari bacaan lain yang lebih berguna, (2) Karena gambar menerangkan cerita, anak yang kurang mampu membaca tidak akan berusaha membaca teks, (3) Lukisan, cerita dan bahasa kebanyakan komik bermutu rendah, (4) Komik menghambat anak melakukan bentuk permainan lainnya, (5) Dengan menggambarkan perilaku anti sosial, komik mendorong tumbuhnya agresivitas dan kenakalan remaja pada anak, dan (6) Komik menjadikan kehidupan yang sebenarnya menjadi membosankan dan tidak menarik.

Berdasarkan paragraf di atas sama halnya yang diungkapkan oleh Zulaekah \& Hamida (2012: 68) Kelebihan komik menurut adalah (1) Komik dapat memperkaya kecerdasan visual dan bisa mendorong anak belajar mencocokan antara latar belakang dengan kejadian yang dipaparkan dalam cerita (2) Komik punya peranan yang positif yaitu mengembangkan kebiasaan membaca (3) Komik juga dapat membantu pemahaman anak tentang suatu informasi.

Media grafis termasuk media visual, didefinisikan sebagai media yang mengkombinasikan fakta dan gagasan secara jelas dan kuat melalui suatu kombinasi pengungkapan kata-kata, dan gambar-gambar. Jenis-jenis media grafis yang dapat dimanfaatkan dalam pembelajaran meliputi bagan, diagram, poster, kartun dan komik.

Menurut Sudjana \& Rivai (2011: 68) luasnya popularitas komik telah mendorong banyak guru yang bereksperimen untuk memasukan dalam pembelajaran. Dalam rangka pengenalan komik sebagai media instruksional, guru dapat menggunakan media komik untuk mengenalkan pembelajaran secara mandiri.

\section{Kemandirian Belajar}

Menurut Nurhayati (2011: 131) menjelaskan bahwa kemandirian berarti kebebasan untuk mengambil inisiatif, mengatasi hambatan, melakukan sesuatu dengan tepat, gigih dalam usaha dan melakukan sendiri segala sesuatu tanpa orang lain. kemandirian belajar merupakan bentuk belajar yang memberikan kesempatan kepada pembelajar untuk menentukan tujuan, sumber, dan kegiatan belajar sesuai dengan kebutuhan sendiri. Dalam proses belajar, pembelajar dapat berpartisipasi secara aktif menentukan apa yang akan dipelajari dan bagaimana cara mempelajarinya.

Dengan demikian kemandirian adalah suatu pekerjaan yang timbul pada individu dan menumbuhkan inisiatif dari individu sendiri untuk mengerjakan sesuatunya tanpa mengandalkan orang lain. Oleh karena itu kemandirian harus tertanam oleh setiap individu untuk menumbuhkan kepercayaan diri untuk melakukan sesuatu tanpa mengandalkan orang lain. Begitu pula dengan kemandirian belajar, siswa harus bisa menumbuhkan kemandiriannya dalam belajar agar tidak terus-menerus mengandalkan atau kebergantungan pada orang lain, sedangkan kemandirian belajar adalah kegiatan belajar dengan kemampuan sendiri dan kompetensi yang telah dimiliki meliputi perilaku mampu berinisiatif, mampu mengatasi masalahnya sendiri tanpa bergantung kepada orang lain, mempunyai rasa percaya diri, disiplin, dan tanggung jawab yang tinggi, serta melakukan kontrol diri.

Adapun faktor kemandirian belajar adalah salah satu yang mempengaruhi dalam proses pembelajaran, sebab itu belajar setiap individu belum bisa berkembang karena tidak adanya dorongan dari setiap individunya sendiri untuk lebih baik dalam belajar. Menurut Sukardi \& Astuti (2013: 336) misalnya, memandang belajar sebagai proses kognitif yang dipengaruhi oleh beberapa faktor seperti keadaan individu, pengetahuan sebelumnya, sikap, pandangan individu, konten, dan cara penyajian. Satu sub-faktor penting dari keadaan individu yang mempengaruhi belajar adalah kemandirian belajar (self-regulated learning).

Menurut Astuti, (2015: 14) mengemukakan bahwa terdapat beberapa hal yang dapat dilakukan untuk meningkatkan kemandirian anak sebagai berikut: (1) Beri kesempatan memilih, anak yang terbiasa berhadapan dengan situasi atau hal-hal yang sudah ditentukan oleh orang lain, akan malas untuk melakukan pilihan sendiri, (2) Hargailah usahanya, hargailah sekecil apapun usaha yang diperlihatkan anak untuk mengatasi sendiri kesulitan yang dihadapi, (3) Hindari banyak bertanya Pertanyaan-pertanyaan yang diajukan orang tua, yang sebenarnya dimaksudkan untuk menunjukkan perhatian pada si anak, dapat diartikan sebagai sikap yang terlalu banyak mau tahu. 
Karena itu hindari kesan cerewet, (4) Jangan langsung menjawab pertanyaan, meskipun salah tugas orang tua adalah memberi informasi serta pengetahuan yang benar kepada anak, namun sebaiknya orang tua tidak langsung menjawab pertanyaanpertanyaan yang diajukan. Sebaliknya, berikan kesempatan padanya untuk menjawab pertanyaan tersebut, (5) Dorong untuk melihat alternatif, sebaiknya anak pun tahu bahwa untuk mengatasi suatu masalah, orang tua bukanlah satu-satunya tempat untuk bertanya, 6) Jangan patahkan semangatnya, tak jarang orang tua ingin menghindarkan anak dari rasa kecewa dengan mengatakan "mustahil" terhadap apa yang sedang diupayakan anak. Sebenarnya apabila anak sudah mau memperlihatkan keinginan untuk mandiri, dorong untuk terus melakukanya.

\section{Penggunaan Bahan Ajar Komik terhadap Kemandirian Belajar Siswa}

Penggunaan bahan ajar pada proses pembelajaran matematika dibuthkan oleh seorang guru. Salah satu bahan ajar yang dapat digunakan oleh seorang guru untuk menumbuhkan kemandirian belajar siswa yaitu menggunakan bahan ajar komik. Menurut Sudjana \& Rivai (2011: 68) luasnya popularitas komik telah mendorong banyak guru yang bereksperimen untuk memasukan dalam pembelajaran. Dalam rangka pengenalan komik sebagai media instruksional, guru dapat menggunakan media komik untuk mengenalkan pembelajaran secara mandiri.

Sedangkan menurut Rohani (1997: 79) peranan pokok dari buku komik dalam pengajaran adalah kemampuannya dalam menciptakan minat para siswa. Penggunaan komik dalam pengajaran sebaiknya dipadukan dengan metode mengajar, sehingga komik dapat menjadi alat pengajaran yang efektif. Komik merupakan suatu bentuk bacaan dimana anak membacanya tanpa harus dibujuk. Melalui bimbingan dari guru komik dapat berfungsi sebagai jembatan untuk menumbuhkan motivasi belajar para siswa.

Beberapa pemaparan paragraf di atas selaras dengan yang diungkapkan oleh Daryanto (2010: 127) bahwa pembelajaran matematika menggunakan media komik efektif karena tujuan pembelajaran matematika tersampaikan dengan baik dan dapat membuat siswa semakin paham dengan materi yang diajarkan. Selain itu media komik dapat menumbuhkan ketertarikan siswa untuk membaca bahan ajar sehingga saat proses pembelajaran siswa menjadi aktif.

Sedangkan menurut Syaichudin \& Novianti (2010: 83) mengemukakan bahwa media komik salah satu media yang intruksionalis serta komunikatif untuk pemblajaran matematika. hal ini diperkuat dengan validasi ahli media dan ahli materi bahwa materi matematika yang bersifat abstrak dapat dijadikan ilustrasi atau alur cerita sehingga dapat memvisualisasikan materi matematika menjadi hal yang lebih konkrit atau nyata.

Berdasarkan uraian di atas mengenai komik dan media ajar, keduanya saling memiliki keterkaitan yakni pada komik dapat memuat pelajaran matematika, tidak hanya di bahan ajar yang dapat memuat itu akan tetapi komik juga dapat termuat di dalamnya. Komik ini dapat digunakan sebagai pusat pembelajaran matematika akan tetapi komik disini hanya sebagai suplemen bahan ajar, dimana komik ini hanya mendampingi bahan ajar matematika.

Menurut Kamus Bahasa Indonesia (2008: 1394) Suplemen diartikan sebagai penunjang atau tambahan, hal ini jelas bahwa komik hanya mendampingi bahan ajar, untuk pusat pembelajaran tetap berpusat pada buku yang sudah tersedia. Dengan hal ini diharapkan siswa akan tertarik untuk membacanya sebelum difokuskan pada bahan ajar yang tersedia, sehingga siswa akan dapat fokus dan terarah di dalam proses pembelajaran hingga selesai, dikarenakan sebelum pembelajaran berlangsung siswa akan dapat gambaran terlebih dahulu yakni menggunakan komik matematika tersebut.

Di samping itu diharapkan siswa akan dapat menumbuhkembangkan kemandirian belajarnya, karena dengan siwa belajar sendiri tanpa bantuan orang lain maka siswa akan memiliki tanggung jawab dan disiplin terhadap dirinya sendiri.

\section{METODE PENELITIAN}

Metode yang digunakan dalam penelitian ini adalah metode statistik deskriptif dengan desain penelitian The OneShot Case Study Design. Subjek pada penelitian ini yaitu siswa-siswi di Sekolah MTs Islamic Center, sedangkan sample yang digunakan yaitu seluruh kelas VIII yaitu kelas VIII A, VIII B, dan VIII C sehingga 
subjek penelitian ini adalah 66 siswa, dimana penelitian ini memiliki perlakuan yang berbeda-beda yaitu kelas C menggunakan komik secara intens, kelas B menggunakan komik tidak secara intens (jarang-jarang), dan Kelas A tidak menggunakan komik. Pengumpulan data dilakukan setelah diberi perlakukan diperoleh dari angket, kemudian dianalisis menggunakan One-Way ANOVA.

\section{HASIL PENELITIAN DAN PEMBAHASAN}

Sikap siswa terhadap pembelajaran matematika yang menggunakan komik secara intens dan tidak secara intens (jarangjarang) merupakan tanggapan siswa terhadap penggunaan bahan ajar komik dalam proses pembelajaran matematika. Sikap siswa terhadap penggunaan komik diukur dengan angket. Berdasarkan hasil perhitungan angket respon terhadap penggunaan komik dalam pembelajaran matematika antara kelas yang menggunakan secara intens dan tidak intens (jarang-jarang) tidak memiliki perbedaan yang nyata. Rata-rata respon yang diperoleh oleh kelas yang menggunakan komik tidak secara intens yaitu sebesar 69,90\% sedangkan kelas yang menggunakan komik secara intens memperoleh rata-rata sebesar $72,32 \%$. Dari dua persentase tersebut maka dapat disimpulkan bahwa respon siswa terhadap penggunaan komik dapat dikategorikan baik keduanya. Akan tetapi kelas yang menggunakan komik secara intens dalam pembelajaran matematika lebih unggul sedikit yaitu sebesar $72,32 \%$, hal ini jelas yang menggunakan komik secara intens mempunyai perbedaan dengan yang menggunakan tidak secara intens (jarang-jarang) walaupun perbedaanya tidak signifikan antara keduanya. Perbedaan itulah yang menjadikan tolak ukur pengaruhnya bahan ajar yang diterapkan dalam proses pembelajaran matematika menggunakan komik, dengan hasil seperti itu jelas bahwa sangat berpengaruh sekali siswa yang menggunakan komik secara intens (selalu) dalam mempelajari matematika.

Hasil tersebut membuat siswa bersemangat dalam belajar matematika menggunakan komik yang dapat dilihat dari indikator angket yang telah diukur kepada siswa bahwa siswa senang belajar matematika menggunakan komik serta aktif bertanya pada saat pembelajaran matematika berlangsung. Selain itu pada indikator memperhatikan pembelajaran matematika lebih unggul yang menggunakan komik secara intens yaitu memiliki rata-rata $76,19 \%$ sedangkan yang menggunkan komik tidak secara intens (jarang-jarang) hanya mendapatkan ratarata $66,36 \%$. Oleh karena itu komik sangat mempengaruhi pada proses pembelajaran berlangsung. Adapun untuk lebih jelasnya dapat digambarkan pada grafik di bawah ini:

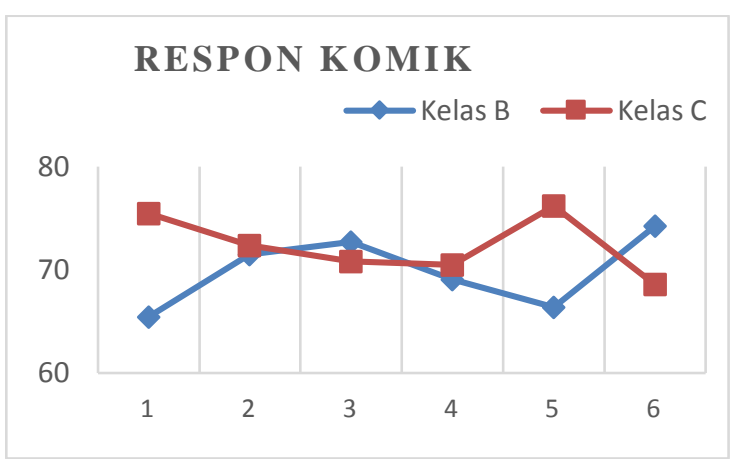

Berdasarkan hasil grafik di atas menyatakan bahwa setiap indikator respon memperoleh skor lebih dari sama dengan $65 \%$ artinya bahwa respon kedua kelas ini sudah baik untuk menerima pembelajaran matematika menggunakan komik. Adapun kelas C mempunyai grafik lebih bagus daripada kelas B, jika dilihat dari perindikatornya kelas $\mathrm{C}$ memiliki 2 indikator dibawah kelas B yaitu indikator 3 dan 6 artinya bahwa skor interpretasi lebih rendah sedangkan kelas B memiliki 4 indikator diawah kelas $\mathrm{C}$ artinya bahwa skor interpretasinya dibawah kelas C. Dari uraian tersebut jelas bahwa yang mempunyai respon baik yaitu kelas C.

Sedangakn hasil kemandirian belajar siswa berdasarkan perhitungan angket yang diperoleh kemandirian belajar siswa kelas A yang tidak menggunakan komik memperoleh skor rata-rata $52,22 \%$ yang dikategorikan cukup tinggi berbeda dengan yang menggunakan komik secara intens dan jarang-jarang. Kemandirian belajar kelas B yang menggunakan komik tidak secara intens (jarang-jarang) memperoleh skor ratarata yang lebih tinggi daripada kela A yaitu sebesar $65,37 \%$ hal ini menunjukan kelas A dan kelas B mempunyai perbedaan yang nyata antara yang menggunakan komik dan tidak menggunkan komik. Sedangkan kemandirian kelas $\mathrm{C}$ yang menggunakan komik secara intens memperoleh skor rata- 
rata sebesar $66,07 \%$, dengan ini kelas $\mathrm{C}$ juga mempunyai perbedaan yang nyata dengan kelas A. Sehingga penerpan bahan ajar komik baik yang secara intens atau tidak secara intens (jarang-jarang) dalam pembelajaran mempengaruhi kemandirian belajar siswa akan tetapi yang tidak menggunakan komik sendiri kemandirian belajarnya digolongkan cukup. Jadi pembelajaran matematika lebih efektif menggunakan komik untuk menumbuhkan kemandirian belajar siswa. adapun untuk lebih jelasnya dapat diliat dari grafik di bawah ini:

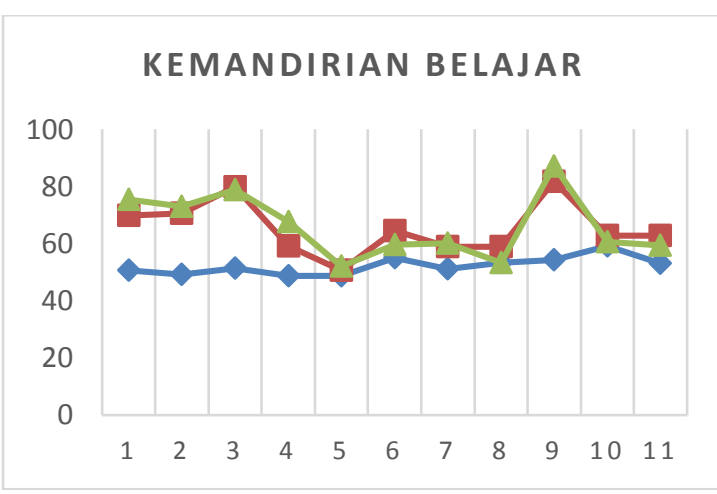

Grafik warna merah yaitu kemandirian kelas A, grafik warna hijau yaitu kemandirian kelas B, grafik warna biru yaitu kemandirian kelas C.

Berdasarkan grafik di atas diperoleh bahwa setiap indikator pada kemandirian belajar siswa yang menonjol adalah kelas B dan C. Jika dilihat dari grafik tersebut kelas $\mathrm{B}$ dan $\mathrm{C}$ mempunyai kesamaan akan tetapi keduanya berbeda. Sedangkan kelas A memperoleh grafik dibawah kelas B dan C, sehingga kelas A setiap indikator mempunyai skor yang rendah dibandingkan kelas B dan C. Oleh karena itu kemandirian kelas A dapat dinyatakan rendah dan kelas $\mathrm{B}$ dan $\mathrm{C}$ kemandiriannya tinggi.

Hal ini ditunjukan oleh Uji ANOVA yaitu memiliki $\mathrm{F}_{\text {hitung }}$ sebesar $=17,198$ dengan $\mathrm{F}_{\text {tabel }}=3,14$ sehingga $\mathrm{F}_{\text {hitung }}>\mathrm{F}_{\text {tabel }}$ maka dapat disimpulkan bahwa $\mathrm{H}_{0}$ ditolak yang menyatakan tidak ada pengaruh antara yang menggunakan komik secara intens, jarangjarang dan tidak menggunkan terhadap kemandirian belajar siswa, karena $\mathrm{H}_{0}$ ditolak maka penelitian menerima $\mathrm{H}_{\mathrm{a}}$ yang berarti menunjukan bahwa adanya pengaruh antara yang menggunakan komik secara intens, jarang-jarang dan tidak menggunkan terhadap kemandirian belajar siswa.

\section{KESIMPULAN DAN SARAN}

Respon siswa terhadap penggunaan bahan ajar matematika bersuplemen komik pada pokok bahasan perbandingan yaitu kelas B yang menggunakan komik tidak secara intens (jarang-jarang) memperoleh persentase rata-rata sebesar $69,90 \%$ sedangkan kelas C yang menggunakan komik secara intens (selalu) memperoleh persentase rata-rata sebesar $72,32 \%$. Hal ini menunjukan bahwa keduanya tergolong baik yakni siswa dapat merespon baik terhadap penggunaan bahan ajar matematika bersuplemen komik pada pembelajaran matematika.

Kemandirian belajar siswa dapat dilihat dari setiap rata-rata setiap indikator yakni siswa kelas A yang tidak menggunakan komik memperoleh persentase rata-rata sebesar $52,22 \%$, siswa kelas B yang menggunakan komik tidak secara intens (jarang-jarang) memperoleh prosestase rata-rata sebesar $65,37 \%$ serta siswa kelas C yang menggunakan komik secara intens (selalu) memperoleh persentase rata-rata sebesar $66,07 \%$. Hal ini berarti adanya pengaruh antara yang menggunakan komik dan tidak terhadap kemandirian belajar siswa tersebut. Kelas A yang memperoleh persentase tersebut dapat digolongkan kemandiran belajarnya yaitu cukup tinggi sedangkan kelas $\mathrm{B}$ dan $\mathrm{C}$ yang menggunakan komik dengan persentase tersebut dapat digolongkan kemandirian belajarnya tinggi.

Hasil penelitian menunjukan bahwa adanya pengaruh antara yang menggunakan komik secara intens, jarang-jarang, serta tidak menggunakan komik terhadap kemandirian belajar siswa. Hal ini ditunjukan dengan Uji ANOVA yaitu memiliki $F_{\text {hitung sebesar }}=17,198$ dengan $F_{\text {tabel }}$ $=3,14$ sehingga $F_{\text {hitung }}>F_{\text {tabel }}$ maka dapat disimpulkan bahwa $\mathrm{H}_{0}$ ditolak yang menyatakan tidak ada pengaruh antara yang menggunakan komik secara intens, jarangjarang dan tidak menggunkan terhadap kemandirian belajar siswa, karena $\mathrm{H}_{0}$ ditolak maka penelitian menerima $\mathrm{H}_{\mathrm{a}}$ yang berarti menunjukan bahwa adanya pengaruh antara yang menggunakan komik secara intens, jarang-jarang dan tidak menggunkan terhadap kemandirian belajar siswa. 


\section{DAFTAR PUSTAKA}

Suardi, M. (2015). Belajar dan Pembelajaran. Yogyakarta: CV Budi Utama

Daryanto. (2010). Media Pembelajaran. Bandung: PT Sarana Tutorial Nurani Sejahtera.

Kartadinata, S. (2007). Teori Bimbingan dan Konseling. Jurnal Bimbingan dan Konseling 1(5), 1-10.

Sumarmo, Utari. (2006). Pengaruh Intelegensi dan Kemandirian Belajar. Retrieved from: www.ecampus.fkip.unja.ac.id

Soviawati, E. (2011). Pendekatan Matematika Realistik (PMR) untuk Meningkatkan Kemampuan Berfikir Siswa di Tingkat Sekolah Dasar. Jurnal Edisi Khusus, 2(2), 7985.

Karmawati, K. (2007). Penggunaan Komik dalam Pembelajaran Matematika. Hunafa: Jurnal Studia Islamika, 4(2), 121-128.

Hakim, L. (2009). Perencanaan Pembelajaran. Bandung: CV Wacana Prima.

Hosnan, M. (2014). Pendekatan saintifik dan kontekstual dalam pembelajaran abad 21: kunci sukses implementasi Kurikulum 2013. Jakarta: Ghalia Indonesia

Nuroeni, dkk, (2013). Pengembangan Multimedia Komik Pembelajaran Matematika Berbasis Kontekstual untuk Bahan Ajar Kpk dan Fpb. Jurnal Ekuivalen-Pendidikan Matematika, 5(1), 79-80.

Nurseto, T. (2011). Membuat Media Pembelajaran yang Menarik. Jurnal Ekonomi \& Pendidikan, 8(1), 19-35.

Supriyanto, B. (2014). Penerapan Discovery Learning Untuk Meningkatkan Hasil Belajar Siswa Kelas VI B Mata Pelajaran Matematika Pokok Bahasan Keliling dan Luas Lingkarandi SDN Tanggul Wetan 02 Kecamatan Tanggul Kabupaten Jember. Jurnal Pancaran Pendidikan, 3(2), 165-174

Hamida, K., \& Zulaekah, S. (2012). Penyuluhan Gizi Dengan Media Komik Untuk Meningkatkan Pengetahuan Tentang Keamanan Makanan Jajanan. Jurnal Kesehatan Masyarakat, 8(1), 67-73.
Ripai, Ahmad. (2013). Media Pembelajaran Teori dan Praktek. Cirebon: Nurjati Press.

Zulkifli. (2010). Pengaruh media komik terhadap hasil belajar kimia siswa pada konsep reaksi redoks: penelitian kuasi eksperimen di SMAN 87 Jakarta. Skripsi. FITK Universitas Islam Negeri Syarif Hidayatullah Jakarta. http://repository.uinjkt.ac.id/dspace/ handle/123456789/21392.

Nurhayati, E. (2011). Psikologi pendidikan inovatif. Yogyakarta: Pustaka Pelajar.

Astuti, R. D. (2015). Teknik Modeling Dalam Bimbingan Kelompok Untuk Meningkatkan Kemandirian Belajar Siswa SMA Negeri 3 Yogyakarta. Doctoral dissertation, UIN Sunan Kalijaga Yogyakarta. Retrieved from: http://digilib.uinsuka.ac.id/id/eprint/16595

Nalurita, L., Siroj, R. A., \& Ilma, R. (2013). Bahan Ajar Kesebangunan Dan Simetri Berbasis Contextual Teaching And Learning (CTL) Menggunakan Macromedia Flash Di Kelas 5 Sekolah Dasar. Jurnal Pendidikan Matematika, 4(1), 48.

Nugraha, D. A., \& Binadja, A. (2013). Pengembangan Bahan Ajar Reaksi Redoks Bervisi SETS, Berorientasi Konstruktivistik. Journal of Innovative Science Education, 2(1), 28.

Widodo, C. S., \& Jasmadi, S. T. P. (2008). Panduan menyusun bahan ajar berbasis kompetensi. Jakarta: Elex Media Komputindo.

Prastowo, A. (2011). Panduan kreatif membuat bahan ajar inovatif. Jogjakarta: DIVA Press.

Sudjana, N., \& Rivai, A. (2011). Media pembelajaran. Bandung: Sinar Baru Algesindo.

Nurhayati, E. (2011). Psikologi pendidikan inovatif. Yogyakarta: Pustaka Pelajar.

Astuti, S., \& Sukardi, T. (2013). Faktorfaktor yang Mempengaruhi Kemandirian untuk Berwirausaha pada Siswa SMK. Jurnal Pendidikan Vokasi, 3(3), 334-346.

Astuti, R. D. (2015). Teknik Modeling Dalam Bimbingan Kelompok Untuk Meningkatkan Kemandirian Belajar Siswa SMA Negeri 3 Yogyakarta. 
Doctoral dissertation, UIN Sunan Kalijaga Yogyakarta. Retrieved from: http://digilib.uinsuka.ac.id/id/eprint/16595

Rohani, A. (1997). Media Instruksional Edukatif. Jakarta: Rineka Cipta.

Novianti, R. D., \& Syaichudin, M. (2010). Pengembangan Media Komik Pembelajaran Matematika Untuk Meningkatkan Pemahaman Bentuk Soal Cerita Bab Pecahan Pada Siswa Kelas V SDN Ngembung. Jurnal Teknologi Pendidikan, 10(1), 74-85.

Indonesia, T. R. K. B. (2008). Kamus Bahasa Indonesia. Jakarta: Pusat Bahasa. 